University of Montana

ScholarWorks at University of Montana

\title{
Free-Living Male Mountain White-Crowned Sparrows Exhibit Territorial Aggression Without Modulating Total or Free Plasma Testosterone
}

\author{
Sharon E. Lynn \\ Thomas P. Hahn \\ Creagh W. Breuner \\ University of Montana - Missoula, creagh.breuner@umontana.edu
}

Follow this and additional works at: https://scholarworks.umt.edu/biosci_pubs

Part of the Biology Commons

Let us know how access to this document benefits you.

\section{Recommended Citation}

Lynn, Sharon E.; Hahn, Thomas P.; and Breuner, Creagh W., "Free-Living Male Mountain White-Crowned Sparrows Exhibit Territorial Aggression Without Modulating Total or Free Plasma Testosterone" (2007). Biological Sciences Faculty Publications. 74.

https://scholarworks.umt.edu/biosci_pubs/74

This Article is brought to you for free and open access by the Biological Sciences at ScholarWorks at University of Montana. It has been accepted for inclusion in Biological Sciences Faculty Publications by an authorized administrator of ScholarWorks at University of Montana. For more information, please contact scholarworks@mso.umt.edu. 


\title{
FREE-LIVING MALE MOUNTAIN WHITE-CROWNED SPARROWS EXHIBIT TERRITORIAL AGGRESSION WITHOUT MODULATING TOTAL OR FREE PLASMA TESTOSTERONE
}

\author{
Sharon E. Lynn ${ }^{1,5}$, Thomas P. Hahn ${ }^{2}$, And Creagh W. Breuner ${ }^{3,4}$ \\ ${ }^{1}$ The College of Wooster, Department of Biology, 931 College Mall, Wooster, OH 44691 \\ ${ }^{2}$ University of California-Davis, Neurobiology, Physiology, and Behavior, Davis, CA 95616 \\ ${ }^{3}$ University of Texas-Austin, Integrative Biology, Patterson Laboratories, Room 141, Austin, TX 78712 \\ ${ }^{4}$ The University of Montana, Division of Biological Sciences, 32 Campus Drive, DBS/HS 104, Missoula, \\ MT 59812
}

Abstract. In some species, expression of territorial aggression is accompanied by a rise in testosterone secretion, but in others aggressive behavior is expressed while testosterone levels remain unchanged. Corticosteroid binding globulin (CBG) binds both corticosterone and testosterone in avian plasma. Thus, increasing corticosterone may result in fluctuations in unbound ("free") testosterone; this could result in greater biological activity of testosterone without an increase in testosterone secretion. We investigated whether such plasma interactions of testosterone, corticosterone, and $\mathrm{CBG}$ might result in alterations of free testosterone in male Mountain White-crowned Sparrows (Zonotrichia leucophrys oriantha). We conducted simulated territorial intrusions during incubation and compared total and free testosterone of males captured immediately following a simulated territorial intrusion with that of males captured passively. All experimental males showed aggressive behavior, but apparently did not modulate total or free testosterone relative to controls.

Key words: aggression, corticosteroid binding globulin, free hormone, simulated territorial intrusion, testosterone, Zonotrichia leucophrys oriantha.

\section{Los Machos Silvestres de Zonotrichia leucophrys oriantha Exhiben Agresión Territorial sin Modular la Testosterona Plasmática Total o Libre}

Resumen. En algunas especies, la expresión de las agresiones territoriales es acompañada por un incremento en la secreción de testosterona, pero en otras especies que expresan agresividad territorial los niveles de testosterona se mantienen constantes. La globulina ligadora de corticosteroides (CBG) se liga tanto a la corticosterona como a la testosterona en el plasma de las aves. Así, el aumento de corticosterona puede resultar en testosterona no ligada ("libre").

Manuscript received 13 March 2006; accepted 26 September 2006.

${ }^{5}$ E-mail: slynn@wooster.edu
Esto puede resultar en una mayor actividad biológica de la testosterona sin un aumento en la secreción de la testosterona. Investigamos si estas interacciones plasmáticas de la testosterona, corticosterona y la $\mathrm{CBG}$ pueden resultar en alteraciones de la testosterona libre en machos de Zonotrichia leucophrys oriantha. Realizamos intrusiones territoriales simuladas durante la incubación y comparamos la testosterona total y libre de machos capturados inmediatamente después de la intrusión territorial simulada con la de machos capturados pasivamente. Todos los machos experimentales mostraron comportamiento agresivo, pero aparentemente no modularon la testosterona total o libre con relación a los machos control.

Environmental and social cues are well known to elicit changes in circulating levels of steroid hormones in birds (Wingfield 1985, 1990, Beletsky et al. 1992, Wingfield and Farner 1993). Total levels of plasma steroids are often assumed to represent changes in physiological activity at the level of hormone receptors; however, growing evidence indicates that the fraction of steroid in plasma that is reversibly bound to a steroid-specific binding globulin may have different physiological activity than the fraction that is unbound, or free. The "free hormone hypothesis" suggests that only unbound hormone is available to enter target tissues and bind to receptors, or be cleared by the liver (Mendel 1989, Ekins 1990). Although additional evidence indicates potential alternative roles for steroid-specific binding globulins (Nakhla et al. 1988, Strel'chyonok and Avvakumov 1991; reviewed by Breuner and Orchinik 2002), support for the free hormone hypothesis is widespread (Siiteri et al. 1982, Rosner 1990, Bright 1995, Hammond 1995, Breuner and Orchinik 2002, Gozansky et al. 2005), suggesting that the free fraction of hormone in the plasma is likely the primary mediator of hormone action. Consequently, in this study we focus on the physiological relevance of the free fraction of hormone based on predictions of the free hormone hypothesis.

Two main steroid binding globulins have been identified in vertebrates: sex-hormone binding glob- 
ulins (SHBG), which bind both androgens and estrogens, and corticosteroid binding globulin (CBG), which binds glucocorticoids (Hammond 1990). Surprisingly, a sex-steroid-specific binding globulin has not been identified in birds and, until recently, biologists assumed that testosterone and estradiol circulated unbound in the plasma (Wingfield et al. 1984). However, Deviche et al. (2001) recently identified avian $\mathrm{CBG}$ as a biologically relevant testosterone binding globulin. They demonstrated that $\mathrm{CBG}$ has a relatively high affinity for testosterone and may bind $90 \%-95 \%$ of circulating testosterone under unstressed conditions. Thus, in birds, CBG may function as a regulator of both free corticosterone and free testosterone.

Because avian CBG binds corticosterone and progesterone with higher affinity than it binds testosterone (Deviche et al. 2001), several scenarios may result in a dramatic release of testosterone from CBG. For example, an increase in corticosterone secretion, an increase in progesterone secretion, or a decrease in $\mathrm{CBG}$ levels might result in a rapid increase in free testosterone. Resulting increases in free testosterone might have important behavioral consequences for free-living birds. For example, a surge in circulating free testosterone might significantly increase testosterone availability to receptors in the brain, and thus either initiate rapid changes in behavior (e.g., as a result of membrane receptor binding; Shakil et al. 2002, Remage-Healey and Bass 2005a, 2005b), or influence existing neural circuits and thus enhance future behavioral responses in appropriate contexts (Wingfield et al. 1987). Alternatively, a surge in free testosterone might speed the metabolic clearance of testosterone from the plasma, thus quickly reducing circulating testosterone levels under certain circumstances.

Such plasma interactions of sex steroids, corticosterone, and $\mathrm{CBG}$ might be especially relevant to a free-living bird during aggressive encounters. Testosterone plays an important role in the initiation and maintenance of reproductive behavior (Balthazart 1983, Harding 1983) and is generally associated with the expression of aggressive behavior in temperate-zone birds (Balthazart 1983, Wingfield et al. 1990, Wingfield and Farner 1993). However, patterns of plasma testosterone and expression of aggressive behavior vary among species. In males of some species, expression of aggressive behavior is accompanied by a rise in testosterone secretion (Wingfield 1985, Wingfield and Wada 1989, Wingfield et al. 1990, Wingfield and Hahn 1994), but in others, aggressive behavior is expressed while testosterone levels remain unchanged (Romero et al. 1998, Meddle et al. 2002; see also Wingfield and Hunt 2002).

Several hypotheses exist to explain the uncoupling of aggressive behavior and increased testosterone secretion, suggesting this may reflect differing ecological pressures, such as a short breeding season or the need for a smooth transition to caring for young (Wingfield and Hunt 2002). However, these studies assumed that the lack of increase in testosterone secretion reflected no overall increase in testosterone action. That is, these studies assessed only total circulating testosterone levels, and did not account for fractions that were free or bound to CBG. Thus, the possibility remains that testosterone availability to receptors may be modulated by additional mechanisms, e.g., at the level of binding globulins. We suggest that the interaction of steroid hormones and binding globulins in circulation may result in modulation of free testosterone, potentially eliciting changes in behavior independent of changes in testosterone secretion.

Because avian CBG binds corticosterone and progesterone with similarly high affinity (Deviche et al. 2001), changes in plasma progesterone or corticosterone could potentially elicit changes in free testosterone. Progesterone has been implicated in the activation of aggressive behavior in reptiles (Weiss and Moore 2004) and mammals (Davis and Marler 2003), but evidence for fluctuations of plasma progesterone following a territorial challenge in birds is scant. One study of female Song Sparrows (Melospiza melodia) found no change in plasma progesterone following simulated territorial intrusion during prebreeding, breeding, or molt (Elekonich and Wingfield 2000). We are unaware of similar published studies of male birds. In addition, a study of breeding European Starlings (Sturnus vulgaris) demonstrated that circulating progesterone levels were not high enough to significantly alter estimations of circulating free corticosterone (Love et al. 2004). In contrast, a variety of environmental stimuli are well known to elicit dramatic and rapid increases in corticosterone in birds (Sapolsky et al. 2000). Deviche et al. (2001) estimated that in Dark-eyed Juncos (Junco hyemalis), a rapid increase in corticosterone would dramatically increase free testosterone. Thus, although the role of progesterone in aggressive encounters in male birds is an interesting avenue for future study, we focused the present study on interactions of corticosterone, testosterone, and CBG in regulating free testosterone levels.

We investigated the expression of aggressive behavior and modulation of free and total testosterone in male Mountain White-crowned Sparrows (Zonotrichia leucophrys oriantha) following simulated territorial intrusion (hereafter also referred to as "territorial challenge"). Mountain White-crowned Sparrows breed at mid-latitudes but are constrained to a relatively short breeding season due to their high altitude breeding grounds (Morton 2002). Hence, current hypotheses would predict no increase in testosterone secretion during aggressive encounters (Wingfield and Hunt 2002). We subjected male Mountain White-crowned Sparrows to territorial challenges early in the breeding season and recorded aggressive behavior. We also measured plasma testosterone, corticosterone, and CBG levels following territorial challenge and compared these to levels in free-living males captured without territorial challenges (controls). With these data, we can assess if aggressive behavior during a territorial challenge is accompanied by alterations in biological activity of testosterone through: (1) modulation of testosterone secretion, or (2) elevations in corticosterone secretion, leading to rapid changes in circulating free testosterone. 


\section{METHODS}

\section{STUDY POPULATION AND STUDY AREA}

Our study population of White-crowned Sparrows breeds near Tioga Pass, Mono County, California $\left(\sim 37^{\circ} 30^{\prime} \mathrm{N}, \sim 3000 \mathrm{~m}\right.$ elevation). We captured males $(n=19)$ along Lee Vining Creek and the neighboring Tioga Pass Meadow between 15 and 24 June 2003, when the majority of females in the population were incubating eggs. All males not banded previously were banded with an aluminum U.S. Fish and Wildlife Service band and colored plastic leg bands for identification.

\section{SIMULATED TERRITORIAL INTRUSIONS AND BLOOD SAMPLING}

Nests of all eight experimental males were located at least one day prior to testing. Experimental males were subjected to a territorial challenge in which a caged conspecific male (decoy) and a loop recording of male Mountain White-crowned Sparrow song were placed within $5 \mathrm{~m}$ of the nest. This protocol (described by Wingfield and Ramenofsky [1985]) has been widely used as a standardized method for assessing aggressive behavior in birds. To avoid pseudoreplication we used two decoys and songs recorded from three different males for territorial challenges. Assignment of a decoy and song to each challenge was randomized. During the first $5 \mathrm{~min}$ of the challenge, we recorded the time it took the resident male to approach the decoy (latency), the closest approach the resident male made to the decoy, and the frequency of three behaviors: number of low flights over the decoy (within 1-2 $\mathrm{m}$ vertical distance), number of songs, and number of trills. Songs and flights toward an intruder have been widely recognized as aggressive behaviors among passerines, and trills made by White-crowned Sparrows during male-male encounters are also assumed to relate to aggression (Petrinovich and Patterson 1981).

After $5 \mathrm{~min}$, we stopped recording the male's behavior, and quickly set up a mist net to capture the responding male. We continued the territorial challenge during this time. At capture we collected blood samples (approximately $250 \mu \mathrm{l}$ ) in heparinized microhematocrit capillary tubes following puncture of the alar vein with a 26-gauge needle. The first $50 \mu \mathrm{l}$ (obtained within 3 min of capture) were collected for the corticosterone assay to ensure that plasma corticosterone levels were not elevated due to capture stress (Wingfield et al. 1982). The remaining volume (obtained within $10 \mathrm{~min}$ ) was collected for the CBG and testosterone assays. Plasma was separated by centrifugation, and stored at $-20^{\circ} \mathrm{C}$ until assay.

\section{BLOOD SAMPLING FROM CONTROL MALES}

Eleven male Mountain White-crowned Sparrows, designated as controls, were captured using Potter traps baited with seed. Thus, males were captured when they were foraging, and not while engaged in a territorial interaction. Blood samples were collected in the manner described above. The initial $50 \mu \mathrm{l}$ of blood (obtained within $3 \mathrm{~min}$ of our approach to the trap) was collected for corticosterone assay. The remainder of the blood sample (collected within $10 \mathrm{~min}$ of our approach) was designated for testosterone and $\mathrm{CBG}$ analysis. For two of the control males, corticosterone samples were not obtained within $3 \mathrm{~min}$, and consequently did not represent baseline corticosterone levels (Wingfield et al. 1982). Thus, we only report total testosterone levels for these two birds.

\section{HORMONE ASSAYS}

Plasma hormone levels were evaluated using enzyme immunoassay kits from Assay Designs (Ann Arbor, Michigan). Corticosterone and testosterone assays were optimized for Mountain White-crowned Sparrow plasma. Briefly, pooled plasma from breeding Mountain White-crowned Sparrows was stripped of endogenous steroid using dextran-coated charcoal. Stripped plasma was spiked with hormone (to $200 \mathrm{pg} \mathrm{ml}^{-1}$ corticosterone or $125 \mathrm{pg} \mathrm{ml}^{-1}$ testosterone) and serially diluted $(1: 10,1: 20,1: 40$, and 1:80) with assay buffer of the same hormone concentration. Two dilution series were prepared: one with steroid displacement buffer (Assay Designs; designed to eliminate interference of binding globulins with antibody binding in the assay), and one without. Thus, all dilutions contained the same concentration of hormone, but other plasma components were diluted in a regular way. All eight plasma dilutions $(1: 10,1: 20,1: 40$ and 1:80, with and without steroid displacement buffer) and an external standard were then assayed in triplicate. This allowed us to determine which plasma dilutions allowed for accurate measurement of steroid without extraction. This plasma dilution was subsequently used for samples in the assay. For a more detailed description of the optimization process, see Wada et al. (in press).

Corticosterone assay. Prior to the assay, plasma was incubated for $10 \mathrm{~min}$ with steroid displacement buffer ( $1 \%$ of raw plasma volume, diluted 1:100 before addition to plasma). Treated plasma was then diluted 1:20 with assay buffer for a final dilution of $1: 40$ in the assay. $100 \mu \mathrm{l}$ of diluted, treated plasma was assayed in triplicate. Sensitivity was $0.6 \mathrm{ng} \mathrm{ml}^{-1}$, and the intra-assay coefficient of variation was $7 \%$. Cross-reactivity of the corticosterone antibody was as follows: testosterone $<1 \%$, progesterone $<1 \%$, and estradiol $<1 \%$ (Assay Designs).

Testosterone assay. Plasma was run at a 1:20 dilution. Steroid displacement buffer was not used in this assay, as optimization studies determined binding globulins did not interfere with binding at a 1:20 dilution (M. Swett and CWB, unpubl. data). Sensitivity was $0.4 \mathrm{ng} \mathrm{ml}^{-1}$, and the intra-assay coefficient of variation was $5 \%$. Cross-reactivity of the testosterone antibody was as follows: androstenedione $7.2 \%$, estradiol $<1 \%$, dehydroepiandrosterone $<1 \%$, dihidrotestosterone $<1 \%$, and progesterone $<1 \%$ (Assay Designs).

\section{CORTICOSTEROID BINDING GLOBULIN ASSAY}

For both competition and individual point sample analysis, assays were performed as described in Breuner and Orchinik (2001). Briefly, plasma samples 
were charcoal stripped, and incubated with $\left[{ }^{3} \mathrm{H}\right]$ corticosterone for $2 \mathrm{hr}$ at $4^{\circ} \mathrm{C}$. Final plasma dilution was 1:900. Bound and free fractions were separated by vacuum filtration over glass-fiber filters soaked in a polycationic solution. To determine $K_{i}$ (the inhibition constant, an estimate of affinity), competition assays were completed using pooled Whitecrowned Sparrow plasma incubated with $1.5 \mathrm{nM}$ $\left[{ }^{3} \mathrm{H}\right]$-corticosterone and $0.1 \mathrm{nM}-1 \mu \mathrm{M}$ unlabelled steroid (either corticosterone or testosterone). To estimate individual CBG capacity (point sample analysis), stripped plasma samples were incubated with $20 \mathrm{nM}\left[{ }^{3} \mathrm{H}\right]$-corticosterone with and without $1 \mu \mathrm{M}$ corticosterone to determine nonspecific binding. To avoid interassay variation, all samples were run at once. Based on affinity estimates for Mountain White-crowned Sparrows (Breuner et al. 2003; $K_{d}$ [dissociation constant] $=3.7 \pm 0.3 \mathrm{nM}), 20 \mathrm{nM}\left[{ }^{3} \mathrm{H}\right]-$ corticosterone should occupy $\sim 91 \%$ of total binding sites.

\section{FREE HORMONE CALCULATIONS}

We estimated free hormone levels using the equation of Barsano and Baumann (1989), rather than measuring free hormone directly. Recent studies in mammals have demonstrated a high correlation between direct free corticosterone measures and estimations of free corticosterone (Taymans et al. 1997, Adcock et al. 2006). Whereas direct measures of free corticosterone (e.g., by ultrafiltration) account for albumin-bound hormone, albumin's role in binding corticosterone is not incorporated into Barsano and Bauman's (1989) model for estimating free hormone. However, because the affinity of albumin for corticosterone is quite low, corticosterone that is bound to albumin is considered biologically active (Taymans et al. 1997). Thus, estimations of free hormone made using Barsano and Bauman's (1989) equation may provide a more biologically relevant measure of free hormone than direct measurement by ultrafiltration.

Free corticosterone titers were estimated using total hormone, CBG capacity, and the dissociation constant $\left(K_{d}\right)$ of corticosterone for CBG (Barsano and Baumann 1989). Individual CBG capacity estimations for corticosterone represent approximately $91 \%$ of $\mathrm{B}_{\max }$ (i.e., the total binding capacity of $\mathrm{CBG}$ ), so capacity values were increased to $100 \%$ for free corticosterone calculations.

Free testosterone was estimated using the percent CBG not bound by corticosterone. There is presently no equation to determine percent hormone bound to binding globulin for two hormones concurrently. Hence, it is necessary to calculate percent CBG saturated by the higher affinity ligand, and then use the remaining capacity available for the second ligand (Deviche et al. 2001, Zysling et al. 2006). Testosterone has approximately seven-fold lower affinity for CBG than corticosterone (Fig. 1). Therefore, free corticosterone was determined first, and free testosterone estimates were calculated using total testosterone, CBG available after corticosterone had bound, and estimates of the affinity of testosterone for $\mathrm{CBG}\left(K_{i}=9.1 \mathrm{nM}\right.$ for Mountain White-crowned Sparrow; Fig. 1).

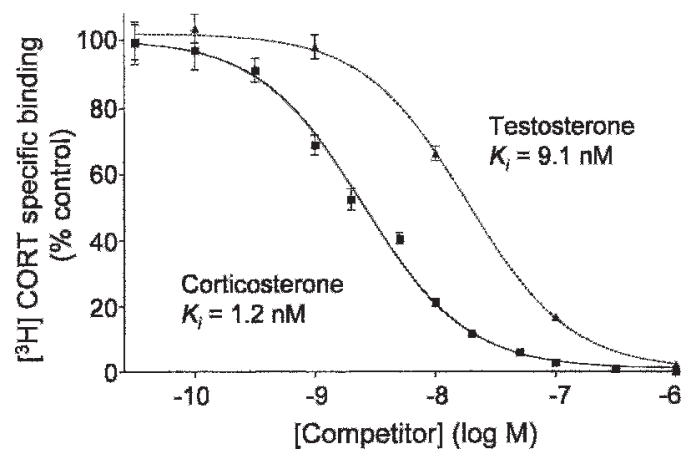

FIGURE 1. Competition curves demonstrating specific binding (as a percentage of control) of $\left[{ }^{3} \mathrm{H}\right]-$ corticosterone $\left(\left[{ }^{3} \mathrm{H}\right]\right.$ CORT) as a function of increasing concentrations of unlabeled corticosterone (squares and solid line) or testosterone (triangles and dotted line). The resulting $K_{i}$ (inhibition constant) for each curve is an estimate of the affinity of $\mathrm{CBG}$ for corticosterone or testosterone, and indicates that affinity for corticosterone is higher than affinity for testosterone. Points indicate mean $\pm \mathrm{SE}$ of triplicate samples at each concentration.

\section{STATISTICAL ANALYSES}

Binding parameter estimates from the competition analyses were obtained by fitting untransformed data to appropriate equations using iterative, least-squares curve-fitting techniques (GraphPad Prism 2005). We log-transformed all hormone data to stabilize variances and conducted unpaired $t$-tests to compare data for control and experimental males. For experimental males, we conducted simple linear regressions to compare hormone levels (free and total) to the length of the territorial challenge. All statistical tests were conducted using Statview version 5.0.1 for Macintosh (SAS Institute 1999). Values reported are means $\pm \mathrm{SE}$, and the significance level of tests was set at $P<0.05$.

\section{RESULTS}

\section{BEHAVIORAL RESPONSE TO SIMULATED TERRITORIAL INTRUSION}

All eight of the experimental males responded to simulated territorial intrusion with aggressive behavior. Average latency to respond was $36 \pm 14 \mathrm{sec}$ (range $=1-111 \mathrm{sec}$, mode $=1 \mathrm{sec})$. All but one male engaged in low flights over the decoy (mean $=3.6 \pm$ 0.6 flights, $n=8$ ). On average, males approached the decoy to within $4.8 \pm 2.3 \mathrm{~m}$ during the first $5 \mathrm{~min}$ of playback, and resident males responded to simulated territorial intrusion with $17.3 \pm 3.7$ songs and $4.6 \pm$ 2.3 trills.

\section{COMPETITION ANALYSIS}

Mountain White-crowned Sparrow plasma bound both corticosterone and testosterone with high affinity. Competition analysis gave a $K_{i}$ (inhibition 

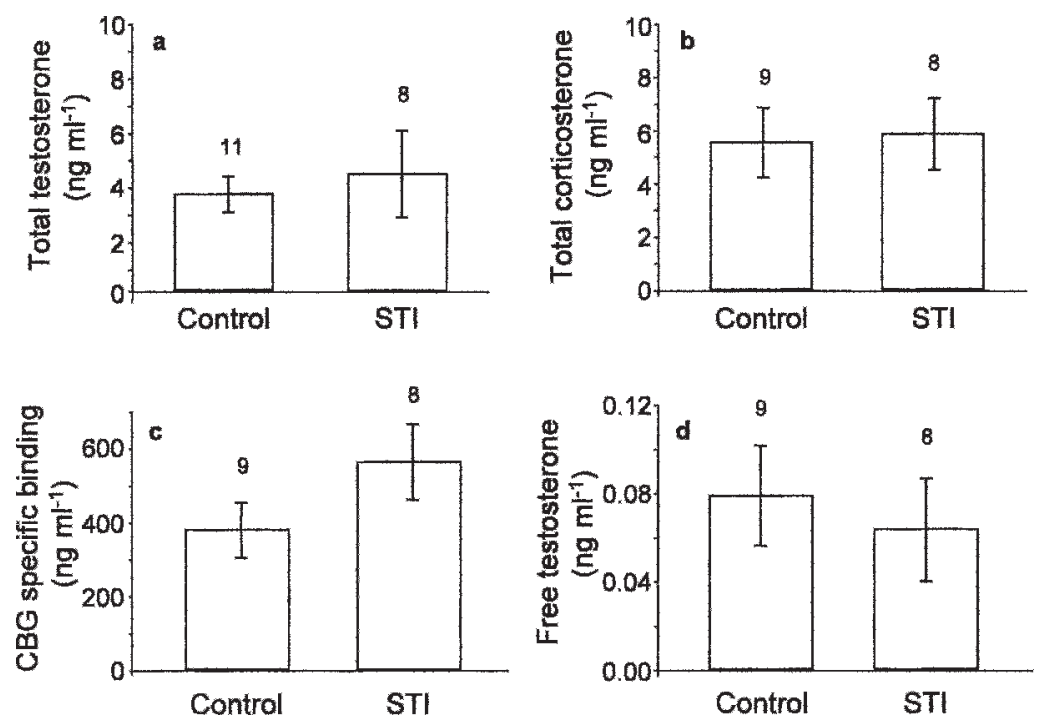

FIGURE 2. Breeding male Mountain White-crowned Sparrows captured either passively (control) or following a simulated territorial intrusion (STI) showed no differences in total plasma testosterone (a), total plasma corticosterone (b), corticosteroid binding globulin, CBG (c), or free testosterone (d) levels. Bars indicate mean $\pm \mathrm{SE}$. Sample sizes are indicated above the bars.

constant) of $1.2 \pm 0.1 \mathrm{nM}$ for corticosterone and 9.1 $\pm 1.6 \mathrm{nM}$ for testosterone (Fig. 1).

\section{HORMONE LEVELS}

Experimental males did not increase plasma testosterone in response to territorial challenge. Total levels of plasma testosterone did not differ between experimental males following territorial challenge and control males captured in Potter traps (unpaired $t$-test, $t_{17}=0.1, P=0.91$; Fig. 2a). Similarly, total plasma corticosterone levels did not differ between experimental and control males (unpaired $t$-test, $t_{15}$ $=-0.1, P=0.89$; Fig. 2b). Experimental males showed a trend toward greater CBG capacity relative to controls (unpaired $t$-test, $t_{15}=-2.0, P=0.06$; Fig. 2c). Calculated values of free corticosterone and free testosterone did not differ between groups (unpaired $t$-tests, free corticosterone: $t_{15}=0.9, P=$ 0.41; free testosterone: $t_{15}=0.8, P=0.42$; Fig. 2d).

Among experimental males $(n=8)$, the duration of territorial challenges ranged from 6.3 to $26.5 \mathrm{~min}$. Challenge duration was not related to levels of total plasma testosterone $\left(r^{2}=0.001, P=0.95\right)$, total plasma corticosterone $\left(r^{2}=0.2, P=0.17\right)$, free testosterone $\left(r^{2}=0.0001, P=0.98\right)$, or free corticosterone $\left(r^{2}=0.2, P=0.20\right)$. Additionally, CBG capacity did not relate to the length of the intrusion $\left(r^{2}=0.02, P=0.78\right)$.

\section{DISCUSSION}

Male Mountain White-crowned Sparrows responded rapidly and aggressively to simulated territorial intrusions. Although we did not measure behavior in the absence of a territorial challenge in our control males, the experimental males exhibited behaviors commonly associated with aggression, and rates of expression of these behaviors were similar to those documented in other studies (Petrinovich and Patterson 1981, Chilton et al. 1995).

We investigated two specific mechanisms by which male Mountain White-crowned Sparrows might modulate testosterone bioavailability following a territorial challenge: (1) direct modulation via increased testosterone secretion, and (2) indirect modulation via increased corticosterone secretion leading to an increase in free plasma testosterone. Although males in our study responded aggressively to territorial challenges, we did not find evidence for either mechanism. Interestingly, although the difference was not significant, there was a trend toward greater CBG capacity in experimental males relative to controls. However, plasma CBG levels did not relate to duration of simulated territorial intrusions, suggesting that this trend may be explained by individual differences in plasma $\mathrm{CBG}$ prior to territorial challenge and not by rapid changes in $\mathrm{CBG}$ in response to territorial challenge. Collectively, our results indicate that the response of males to territorial challenges and plasma testosterone levels were not positively associated during the early breeding season in this population.

Prior studies of other White-crowned Sparrow subspecies have indicated that testosterone and aggression may be uncoupled in severe environments when time to breed is limited. The low elevation, temperate-breeding subspecies ( $Z$. l. pugetensis) modulates testosterone in response to territorial challenges (Wingfield and Hahn 1994), whereas the arctic-breeding subspecies (Z. l. gambelii) does not (Meddle et al. 2002). Our total testosterone data 
support this pattern, as Z. l. oriantha breed in highaltitude meadows where weather can be severe and second broods are uncommon (Morton 2002).

Whereas ecological factors associated with a highaltitude breeding environment may constrain testosterone response in male Mountain White-crowned Sparrows, the possibility remains that plasma interactions of testosterone, corticosterone, and CBG may function to modulate free testosterone levels in other species. For example, testosterone and corticosterone are known to bind to the same binding globulin in at least one other bird species (Dark-eyed Junco; Deviche et al. 2001), an amphibian (Orchinik et al. 2000), a reptile (Jennings et al. 2000), and humans (Brien 1981, Cooke et al. 1996). Though few studies have simultaneously measured testosterone and corticosterone following a territorial challenge, recent work by Van Duyse et al. (2004) indicated that male Great Tits (Parus major) subjected to simulated territorial intrusions had higher corticosterone and lower testosterone following a territorial challenge than did controls at three stages of the breeding season. Within this framework, an increase in corticosterone would displace testosterone from $\mathrm{CBG}$ in the plasma, resulting in a greater tissue level of testosterone that could facilitate expression of aggressive behavior in appropriate contexts, followed by rapid clearance of testosterone from the bloodstream. Van Duyse et al. (2004) did not measure CBG levels, and thus could not calculate free testosterone; however, the decline in total testosterone they report could be explained by rapid clearance of free testosterone from the blood following a rise in corticosterone. In addition, increased corticosterone secretion has been documented during reproductive aggression in at least one other species (Northern Pintails [Anas acuta]; Sorenson et al. 1997, but see Silverin 1993, Wingfield and Lewis 1993). Thus, the hypothesis that plasma interactions of testosterone, corticosterone, and $\mathrm{CBG}$ may regulate testosterone activity at target tissues remains an intriguing possibility. Furthermore, additional factors such as fluctuations in other steroids (e.g., progesterone) may also be important in mediating aggressive responses during the breeding season. Without simultaneously measuring multiple factors following territorial challenges, such mechanisms may be easily overlooked.

Alexa Class, Jamie Cornelius, Elizabeth Derryberry, and Kathleen Hunt provided valuable assistance with fieldwork. We thank Glennis Julian and Haruka Wada for assistance with assays. All animal protocols described here were approved by the University of Texas, Austin, Institutional Animal Care and Use Committee (protocol number 04032904). Funding for this project was provided by National Science Foundation Grant IBN-0236536 (to CWB).

\section{LITERATURE CITED}

Adcock, R. J., H. G. Kattesh, M. P. Roberts, A. M. SAXton, AND J. A. CARroll. 2006. Relationships between plasma cortisol, corticosteroid-binding globulin $(\mathrm{CBG})$ and the free corti- sol index (FCI) in pigs over a $24 \mathrm{~h}$ period. Journal of Animal and Veterinary Advances 5:85-91.

BAlthazART, J. 1983. Hormonal correlates of behavior, p. 221-366. In D. S. Farner, J. R. King, and K. C. Parkes [EDS.], Avian biology. Vol 7. Academic Press, New York.

Barsano, C. P., and G. Baumann. 1989. Simple algebraic and graphic methods for the apportionment of hormone (and receptor) into bound and free fractions in binding equilibria; or how to calculate bound and free hormone? Endocrinology 124:1101-1106.

Beletsky, L. D., G. H. Orians, and J. C. WINGFIELD. 1992. Year-to-year patterns of circulating levels of testosterone and corticosterone in relation to breeding density, experience, and reproductive success of the polygynous Redwinged Blackbird. Hormones and Behavior 26:420-432.

Breuner, C. W., AND M. ORCHINIK. 2001. Seasonal regulation of membrane and intracellular corticosteroid receptors in the House Sparrow brain. Journal of Neuroendocrinology 13:412-420.

Breuner, C. W., AND M. OrChiniK. 2002. Plasma binding proteins as mediators of corticosteroid action in vertebrates. Journal of Endocrinology 175:99-112.

Breuner, C. W., M. Orchinik, R. P. Hahn, S. L. Meddle, I. T. Moore, N. T. Owen-Ashley, T. S. Sperry, AND J. C. Wingfield. 2003. Differential mechanisms for regulation of the stress response across latitudinal gradients. American Journal of Physiology - Regulatory, Integrative and Comparative Physiology 285:R594-R600.

BRIEN, T. G. 1981. Human corticosteroid binding globulin. Clinical Endocrinology 14:193-212.

BRIGHT, G. M. 1995. Corticosteroid-binding globulin influences kinetic parameters of plasma cortisol transport and clearance. Journal of Clinical Endocrinology and Metabolism 80:770-775.

Chilton, G., M. C. Baker, C. D. Barrentine, And M. A. Cunningham. 1995. White-crowned Sparrow (Zonotrichia leucophrys). In A. Poole and F. Gill [EDS.], The birds of North America, No. 183. The Academy of Natural Sciences, Philadelphia, PA, and The American Ornithologists' Union, Washington, DC.

Cooke, R. R., J. E. A. McIntosh, And R. P. MurRAy-Mcintosh. 1996. Effect of cortisol on percentage of non-sex-hormone-bound steroid: implications for distribution of steroids on binding proteins in serum. Clinical Chemistry 42:249-254.

DAvis, E. S., AND C. A. MARler. 2003. The progesterone challenge: steroid hormone changes following a simulated territorial intrusion in female Peromyscus californicus. Hormones and Behavior 44:185-198.

Deviche, P., C. Breuner, AND M. OrchiniK. 2001. Testosterone, corticosterone, and photoperiod interact to regulate plasma levels of binding globulin and free steroid hormone in Dark-eyed 
Juncos, Junco hyemalis. General and Comparative Endocrinology 122:67-77.

EKINS, R. 1990. Measurement of free hormones in blood. Endocrine Reviews 11:5-46.

Elekonich, M. M., AND J. C. Wingfield. 2000. Seasonality and hormonal control of territorial aggression in female Song Sparrows (Passeriformes: Emberizidae: Melospiza melodia). Ethology 106:493-510.

GozAnsky, W. S., J. S. LynN, M. L. LAudenslaGER, AND W. M. KOHRT. 2005. Salivary cortisol determined by enzyme immunoassay is preferable to serum total cortisol for assessment of dynamic hypothalamic-pituitary-adrenal axis activity. Clinical Endocrinology 63:336-341.

GraphPAd Prism. 2005. GraphPad Prism 4. GraphPad Prism, Inc., San Diego, CA.

Hammond, G. L. 1990. Molecular properties of corticosteroid binding globulin and the sexsteroid binding proteins. Endocrine Reviews 11:65-79.

Hammond, G. L. 1995. Potential functions of plasma steroid-binding proteins. Trends in Endocrinology and Metabolism 6:298-304.

HARDING, C. F. 1983. Hormonal influences on avian aggressive behavior, p. 435-468. In B. Svare [ED.], Hormones and aggressive behavior. Plenum Press, New York.

Jennings, D. H., M. C. Moore, R. Knapp, L. MatThews, AND M. ORCHINIK. 2000. Plasma steroid-binding globulin mediation of differences in stress reactivity in alternative male phenotypes in tree lizards, Urosaurus ornatus. General and Comparative Endocrinology 120: 289-299.

Love, O. P., C. W. Breuner, F. Vezina, And T. D. WiLliams. 2004. Mediation of a corticosteroneinduced reproductive conflict. Hormones and Behavior 46:59-65.

Meddle, S. L., L. M. Romero, L. B. Astheimer, W. A. Buttemer, I. T. Moore, And J. C. WINGFIELD. 2002. Steroid hormone interrelationships with territorial aggression in an arcticbreeding songbird, Gambel's White-crowned Sparrow, Zonotrichia leucophrys gambelii. Hormones and Behavior 42:212-221.

Mendel, C. M. 1989. The free hormone hypothesis: a physiologically based mathematical model. Endocrine Reviews 10:232-274.

Morton, M. L. 2002. Mountain White-crowned Sparrow: migration and reproduction at high altitude. Studies in Avian Biology 24.

NAKhla, A. M., M. S. Khan, AND W. Rosner. 1988. Induction of adenylate cyclase in a mammary carcinoma cell line by human corticosteroid-binding globulin. Biochemical and Biophysical Research Communications 153:1012.

Orchinik, M., L. Matthews, And P. J. Gasser. 2000. Distinct specificity for corticosteroid binding sites in amphibian cytosol, neuronal membranes, and plasma. General and Comparative Endocrinology 118:284-301.

Petrinovich, L., And T. L. Patterson. 1981. The responses of White-crowned Sparrows to songs of different dialects and subspecies. Zeitschrift für Tierpsychologie 57:1-14.

Remage-Healey, L., AND A. H. BAss. 2005a. Rapid elevations in both steroid hormones and vocal signaling during playback challenge: a field experiment in Gulf toadfish. Hormones and Behavior 47:297-305.

Remage-Healey, L., AND A. H. Bass. 2005b. Rapid steroid effects on sexually polymorphic vocal patterning. Hormones and Behavior 48:121-122.

Romero, L. M., K. K. Soma, K. M. O’Reilly, R. Suydam, AND J. C. Wingfield. 1998. Hormones and territorial behavior during breeding in Snow Buntings (Plectrophenax nivalis): an arctic-breeding songbird. Hormones and Behavior 33:40-47.

ROSNER, W. 1990. The functions of corticosteroidbinding globulin and sex hormone bindingglobulin: recent advances. Endocrine Reviews 11:80-91.

SAPOLSKY, R. M., L. M. Romero, AND A. U. MUNCK. 2000. How do glucocorticoids influence stress responses? Integrating permissive, suppressive, stimulatory, and preparative action. Endocrine Reviews 21:55-89.

SAS InstituTe. 1999. Statview 5.0.1, power PC version. SAS Institute, Inc., Cary, NC.

Shakil, T., H. A. N. Ehsanul, M. Husain, And D. D. BELSHAM. 2002. Differential regulation of gonadotropin-releasing hormone secretion and gene expression by androgen: membrane vs. nuclear receptor activation. Molecular Endocrinology 16:2592-2602.

Sitteri, P. K., J. T. Murai, G. L. Hammond, J. A. Nisker, W. J. RAymour, And R. W. KuHn. 1982. The serum transport of steroid hormones. Recent Progress in Hormone Research 38:457-510.

Silverin, B. 1993. Territorial aggressiveness and its relation to the endocrine system in the Pied Flycatcher. General and Comparative Endocrinology 89:206-213.

Sorenson, L. G., P. M. Nolan, A. M. Brown, S. R. DERrickson, AND S. L. Monfort. 1997. Hormonal dynamics during mate choice in the Northern Pintail: a test of the 'challenge hypothesis.' Animal Behaviour 54:1117-1133.

Strel'ChyONOK, O. A., AND G. V. Avvakumov. 1991. Interaction of human CBG with cell membranes. Journal of Steroid Biochemistry and Molecular Biology 40:795-803.

Taymans, S., A. C. Devries, M. B. Devries, R. J. Nelson, T. C. Friedman, M. Castro, S. Detera-Wadleigh, C. S. Carter, and G. P. Chrousos. 1997. The hypothalamic-pituitaryadrenal axis of prairie voles (Microtus ochrogaster): evidence for target tissue glucocorticoid resistance. General and Comparative Endocrinology 106:48-61.

Van Duyse, E., R. Pinxten, V. M. Darras, L. ArCKens, AND M. EENS. 2004. Opposite changes in plasma testosterone and corticosterone levels following a simulated territorial 
challenge in male Great Tits. Behaviour 141:451-467.

WADA, H., T. P. HAhN, AND C. W. BREUner. In Press. Binding globulins extend stress hyporesponsive period in altricial White-crowned Sparrow nestlings. General and Comparative Endocrinology.

Weiss, S. L., AND M. C. Moore. 2004. Activation of aggressive behavior by progesterone and testosterone in male tree lizards, Urosaurus ornatus. General and Comparative Endocrinology 136:282-288.

WingFiELD, J. C. 1985. Environmental and endocrine control of territorial behavior in birds, p. 265-277. In B. K. Follett, S. Ishii, and A. Chandola [EDS.], The endocrine system and the environment. Japanese Scientific Societies Press, Tokyo and Springer-Verlag, Berlin.

WINGFIELD, J. C. 1990. Interrelationships of androgens, aggression, and mating systems, p. 187205. In M. Wada, S. Ishii, and C. G. Scanes [EDS.], Endocrinology of birds: molecular to behavioral. Japanese Scientific Societies Press, Tokyo and Springer-Verlag, Berlin.

Wingfield, J. C., G. F. Ball, A. M. Dufty JR, R. E. Hegner, AND M. RAMENOFSKY. 1987. Testosterone and aggression in birds. American Scientist 75:602-608.

Wingfield, J. C., AND D. S. FARNeR. 1993. Endocrinology of reproduction in wild species, p. 163-327. In D. S. Farner, J. R. King, and K. C. Parkes [EDS.], Avian biology. Academic Press, New York.

Wingfield, J. C., AND T. P. Hahn. 1994. Testosterone and territorial behavior in sedentary and migratory sparrows. Animal Behaviour 47: 77-89.

Wingfield, J. C., R. E. Hegner, A. M. Dufty JR., AND G. F. BALL. 1990. The 'challenge hypoth- esis': theoretical implications for patterns of testosterone secretion, mating systems, and breeding strategies. American Naturalist 136:829-846.

Wingfield, J. C., AND K. E. Hunt. 2002. Arctic spring: hormone behavior interactions in a severe environment. Comparative Biochemistry and Physiology B 132:275-286.

Wingfield, J. C., AND D. M. Lewis. 1993. Hormonal and behavioural responses to simulated territorial intrusion in the cooperatively breeding White-browed Sparrow Weaver, Plocepasser mahali. Animal Behaviour 45:1-11.

WingField, J. C., K. S. MAtT, AND D. S. FARner. 1984. Physiologic properties of steroid hormonebinding proteins in avian blood. General and Comparative Endocrinology 53:281-292.

WingField, J. C., AND M. RAMENOFSKY. 1985. Testosterone and aggressive behavior during the reproductive cycle of male birds, p. 92-104. In R. Gilles and J. Balthazart [EDS.], Neurobiology. Springer-Verlag, Berlin.

Wingfield, J. C., J. P. SMith, AND D. S. FARner. 1982. Endocrine responses of White-crowned Sparrows to environmental stress. Condor 84:399-409.

WingField, J. C., AND M. WADA. 1989. Changes in plasma levels of testosterone during male-male interactions in the Song Sparrow, Melospiza melodia: time course and specificity of response. Journal of Comparative Physiology A 166 : 189-194.

Zysling, D. A., T. J. Greives, C. W. Breuner, J. M. Casto, G. E. Demas, And E. D. KetterSON. 2006. Behavioral and physiological responses to experimentally elevated testosterone in female Dark-eyed Juncos (Junco hyemalis carolinensis). Hormones and Behavior 50: 200-207. 